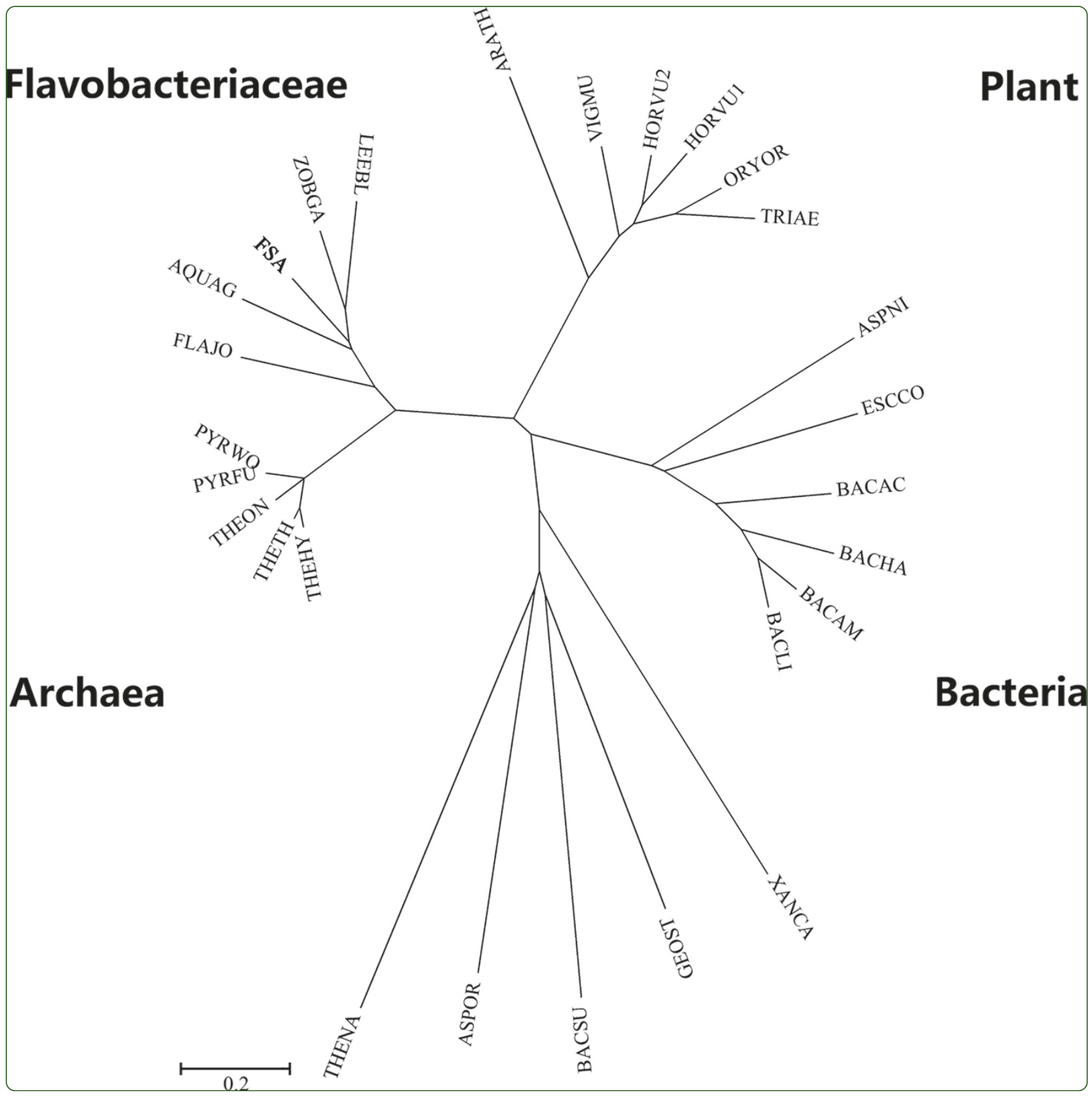

Close relationship of a novel Flavobacteriaceae a-amylase with archaeal a-amylases and good potentials for industrial applications

Li et al. 


\title{
Close relationship of a novel Flavobacteriaceae a-amylase with archaeal a-amylases and good potentials for industrial applications
}

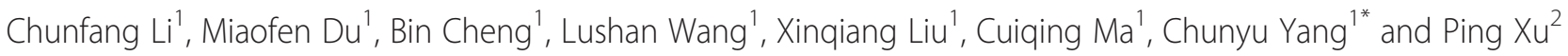

\begin{abstract}
Background: Bioethanol production from various starchy materials has received much attention in recent years. a-Amylases are key enzymes in the bioconversion process of starchy biomass to biofuels, food or other products. The properties of thermostability, pH stability, and Ca-independency are important in the development of such fermentation process.
\end{abstract}

Results: A novel Flavobacteriaceae Sinomicrobium a-amylase (FSA) was identified and characterized from genomic analysis of a novel Flavobacteriaceae species. It is closely related with archaeal a-amylases in the GH13_7 subfamily, but is evolutionary distant with other bacterial a-amylases. Based on the conserved sequence alignment and homology modeling, with minor variation, the $\mathrm{Zn}^{2+}$ - and $\mathrm{Ca}^{2+}$-binding sites of FSA were predicated to be the same as those of the archaeal thermophilic a-amylases. The recombinant a-amylase was highly expressed and biochemically characterized. It showed optimum activity at pH 6.0, high enzyme stability at pH 6.0 to 11.0, but weak thermostability. A disulfide bond was introduced by site-directed mutagenesis in domain $\mathrm{C}$ and resulted in the apparent improvement of the enzyme activity at high temperature and broad pH range. Moreover, about $50 \%$ of the enzyme activity was detected under $100^{\circ} \mathrm{C}$ condition, whereas no activity was observed for the wild type enzyme. Its thermostability was also enhanced to some extent, with the half-life time increasing from 25 to 55 minutes at $50^{\circ} \mathrm{C}$. In addition, after the introduction of the disulfide bond, the protein became a Ca-independent enzyme.

Conclusions: The improved stability of FSA suggested that the domain C contributes to the overall stability of the enzyme under extreme conditions. In addition, successfully directed modification and special evolutionary status of FSA imply its directional reconstruction potentials for bioethanol production, as well as for other industrial applications.

Keywords: a-Amylases, Evolutionary position, Site-directed mutagenesis, Thermostability, Domain C

\section{Background}

As large-scale substitution of petroleum-based fuels is needed for energy security and climate change considerations, bioethanol production from various starchy materials such as corn, wheat, cassava root, and starch have received much attention in recent years $[1,2]$. The starch-degrading enzyme $\alpha$-amylases (EC 3.2.1.1) are the enzymes that hydrolyze starch, glycogen, and related polysaccharides by cleaving $\alpha-1,4$-glucosidic linkages at random, and are regarded as the most important enzymes for bioethanol process, as well as a wide range of

\footnotetext{
* Correspondence: ycy21th@sdu.edu.cn

'State Key Laboratory of Microbial Technology, Shandong University, Jinan 250100, People's Republic of China

Full list of author information is available at the end of the article
}

other industrial applications such as production of detergents, textiles, food, and paper [3]. Economically, it is desirable that the $\alpha$-amylases used in starch liquefaction are active at high temperatures (approximately $90^{\circ} \mathrm{C}$ ) [4]. To obtain ideal industrial enzymes, many comparative analyses and directed evolutions have been performed to elucidate the catalytic properties and stability parameters of glycosyl hydrolase family 13 (GH13) enzymes [5-7]. Moreover, many thermostable $\alpha$-amylases were explored to meet the starch saccharification process. Thermostable $\alpha$-amylases are produced by a wide variety of microorganisms, including thermophiles and mesophiles [8]. Among bacteria, Bacillus sp. is widely used for thermostable $\alpha$-amylase production to meet industrial needs $[9,10]$. In addition, the most thermoactive $\alpha$-amylases 
from hyperthermophilic archaea have attracted increasing attention and have been characterized from Pyrococcus woesei, P. furiosus, Thermococcus profundus, and $T$. hydrothermalis [11-14]. Some general strategies to increase the thermal stability of these enzymes have also been proposed and used for directed evolution, such as change of the secondary structure strengthening the hydrophobic interactions in intermolecular contacts, introduction of hydrogen bonds and salt bridges, and increase of the hydrophobicity of the protein surface $[15,16]$.

Except for the $\alpha$-amylase family 57 , which comprises a few amylolytic enzymes from some hyperthermophiles $[17,18]$, most of the $\alpha$-amylases belong to GH13, based on the classification of Henrissat [19] and the CarbohydrateActive Enzymes (CAZy) database at: http://www.cazy.org [20]. In this classification, GH13 is found to be the largest family of glycoside hydrolases, comprising the majority of the enzymes acting on starch, glycogen, and related oligoand polysaccharides [21]. GH13 has been subdivided into 40 subfamilies on the basis of sequence similarity and phylogenetic reconstruction criteria [21,22]. Based on this division, the phylogeny of $\alpha$-amylases is generally in agreement with their origin, such that most of the bacterial $\alpha$-amylases are assigned to the GH13_5 subfamily, whereas GH13_6 includes $\alpha$-amylases from plants, and the GH13_7 group comprises $\alpha$-amylases of archaeal origin [21]. However, there are also some exceptions from such criteria, such as the close relationship between plant and archaeal $\alpha$-amylases $[8,23,24]$. In addition, as inferred from the CAZy database, there is also another interesting exception for bacterial $\alpha$-amylases: the hypothetic Flavobacteriaceae $\alpha$-amylases belong to the GH13_7 subfamily, together with thermophilic archaeal $\alpha$-amylases [20,25].

The family Flavobacteriaceae is one of the largest branches in the phylum Bacteroidetes. In this study, genomic analysis of a new species of this family revealed the presence of an open reading frame (ORF) encoding a novel $\alpha$-amylase of Flavobacteriaceae Sinomicrobium (FSA). Since no such $\alpha$-amylase was characterized and no evolutionary relationship was reported to date, in the present study, the evolutionary position, catalytic properties, and conserved regions of FSA were analyzed.

\section{Results}

\section{Phylogenetic analysis}

The phylogenetic analysis of the sequence of $16 \mathrm{~S}$ rRNA gene revealed that strain 5DNS001 is a member of the family Flavobacteriaceae and exhibits the highest identity (96.3\%) with Sinomicrobium oceani [26]. Based on the many differences with its relative strains, 5DNS001 would be classified as a novel species of the genus Sinomicrobium and designated as Sinomicrobium sp. 5DNS001.
Based on the annotation results of the genomic information of 5DNS001, a 1437-bp gene encoding a novel $\alpha$-amylase exhibits the highest identity (65.1\%) with the putative $\alpha$-amylase of the Flavobacteriaceae species Zobellia galactanivorans, and $50.8 \%$ identity with the putative $\alpha$-amylase of the Flavobacteriaceae species Flavobacterium johnsoniae (FLAJO). Moreover, in comparison with other identified proteins, FSA exhibits the highest identity of $43.8 \%$ with the $\alpha$-amylase of $P$. woesei (PWA). However, it shows lower than $30 \%$ identity with the $\alpha$-amylases from other bacteria or from the plant. The deduced amino acid sequence of the $\alpha$-amylase coding region includes a putative signal peptide of 26 amino acids and the mature enzyme of 452 amino acids. As shown in Figure 1, in comparison with plant, fungal, and other bacterial amylases, amylases from thermophilic archaea and Flavobacteriaceae clearly showed the nearest evolutionary relatedness when placed on adjacent branches of a larger common cluster. The Flavobacteriaceae $\alpha$-amylases were clustered together with hyperthermophilic archaeal $\alpha$ amylases of the family Thermococcaceae. In addition, the plant $\alpha$-amylases were closest to this cluster whereas other origins from fungi and bacteria were located at further distances.

\section{Multiple alignments}

As predicted by PSIPRED and based on the homology model of Figure 2, FSA contains three distinct domains (A, B, and C) and shares outstanding similarity to other $\alpha$-amylases. Domain A, containing residues 1 to 155 and 216 to 393 , folds into an $(\alpha / \beta)_{8}$-barrel. As shown in Figure 3 of multiple sequence alignments, most of the highly conserved residues are located at domain A, especially at the six conserved regions of strands $\beta 2, \beta 3, \beta 4$, $\beta 5, \beta 7$, and $\beta 8$. Besides the three established active site residues of Asp247 in $\beta 4$, Glu272 in $\beta 5$, and Asp334 in $\beta 7$ (unless otherwise specified, all amino acid numbering correspond to FSA), several residues are well conserved along all three subfamilies of GH13_5, GH13_6, and GH13_7: Gly85, Trp90, Pro92, Val152, Asn154, His155, Arg245, Asp247, Val269, Trp273, Asn332, Gly363, Pro364, Tyr368, and Phe377. Some of these conserved residues locate in the active center and interact with a number of highly conserved connections (that is, $\beta 4, \beta 5$, and $\beta 7$ of the $(\alpha / \beta)_{8}$-barrel), such as the carboxyl groups of Trp273, Arg245, and Phe292 form hydrogen bonds with acarbose and predicted to be substrate-binding sites [15]. In addition, the conserved His155 locating near the $\mathrm{Ca}^{2+}$ serves as a $\mathrm{Ca}^{2+}$-binding site [15]. As shown in Figure 3, in addition, some residues are shared by both the GH13_5 and GH13_6 subfamilies (that is, Leu91, Ala149, Trp244, and Gly251) and others are shared only by the GH13_5 subfamily (that is, Ile89, Val147, and Tyr258). Furthermore, some residues are exclusive of the Flavobacteriaceae 


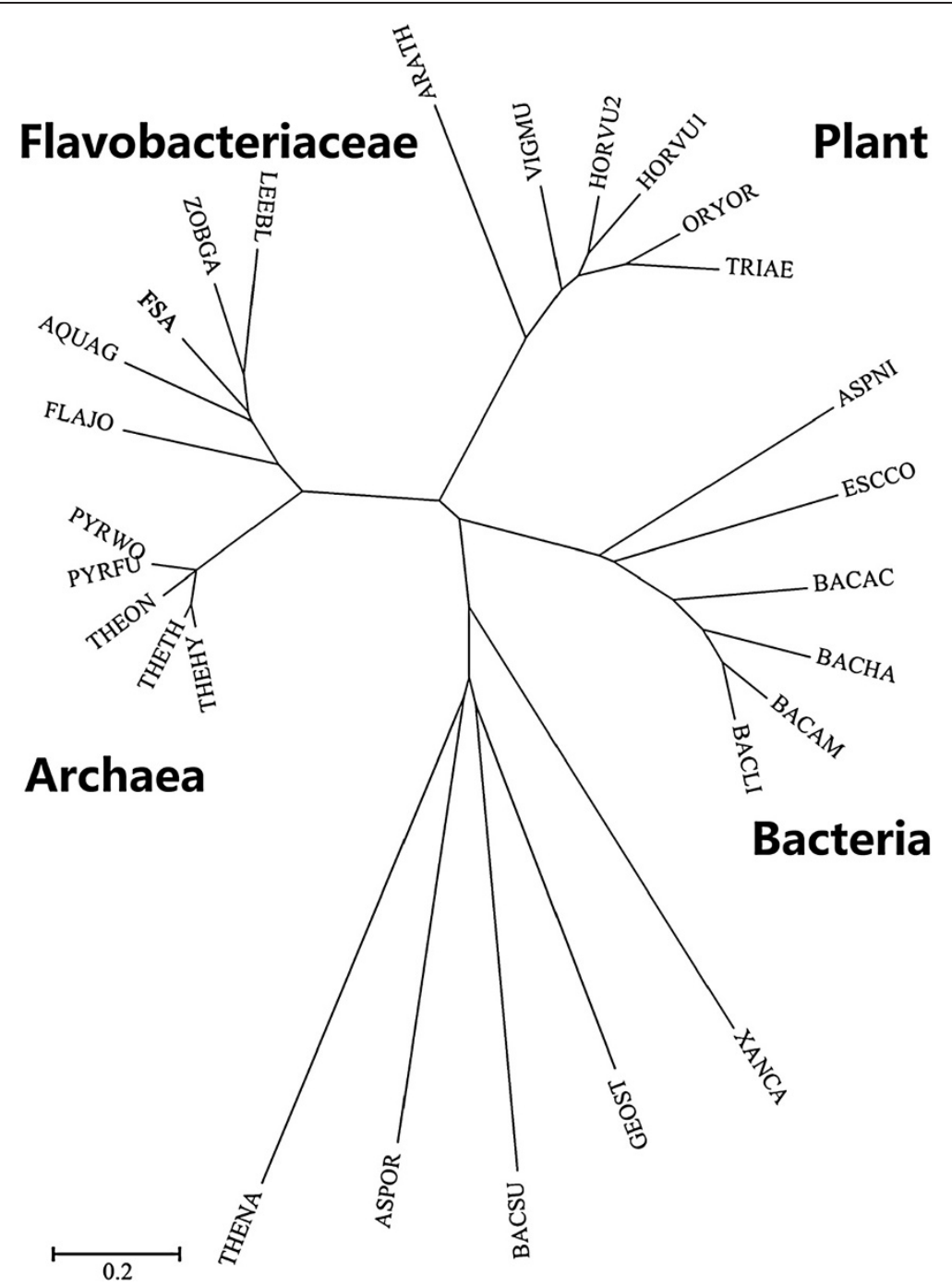

Figure 1 Phylogenetic tree of FSA and its closest relatives. FSA, Flavobacteriaceae Sinomicrobium a-amylase, present study; LEEBL,

Leeuwenhoekiella blandensis; ZOBGA, Zobellia galactanivorans; FLAJO, Flavobacterium johnsoniae; AQUAG, Aquimarina agarilytica; PYRFU, Pyrococcus furiosus; PYRWO, P. woesei; THEHY, Thermococcus hydrothermalis; THEON, T. onnurineus; THETH, T. thioreducens; ARATH, Arabidopsis thaliana; VIGMU, Vigna mungo seed; ORYOR, Oryzeae Oryza; TRIAE, Triticum aestivum; HORVU1, Hordeum vulgare; HORVU2, H. vulgare; ASPOR, Aspergillus oryzae; ASPNI, A. niger; THENA, Thermotoga naphthophila; ESCOO, Escherichia coli; GEOST, Geobacillus stearothermophilus; BACLI, Bacillus licheniformis; BACSU, B. subtilis; BACAC, B. acidicola; BACHA, B. halmapalus; BACAM, B. amyloliquefaciens; XANCA, Xanthomonas campestris. Bootstrap percentages $>50 \%$ (based on 1,000 replications) are shown at branch points.

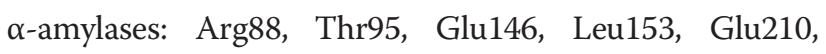
Leu213, Phe252, Ser268, Tyr363, and Thr365. In addition, Ala331 in the $\mathrm{i}-3$ position from the transition state stabilizer Asp334 is only conserved in GH13_5.

Domain B of FSA (residues 156 to 216) inserted between the secondary structures $\alpha 3$ and $\beta 3$ is one of the smallest $\alpha$-amylase B domains. It is constituted of short $\beta$-sheets (three to four residues). As indicated from multiple alignments, BACLI and ASPNI have the longest $B$ domains consisting of up to 100 residues, whereas the four thermophilic archaeal $\alpha$-amylases together with FLAJO have the shortest regions consisting of 58 residues [15]. The remaining two Flavobacteriaceae $\alpha$-amylases have the same size of 61 residues with the two plants of $\alpha$-amylases. The five residues involved in $\mathrm{Ca}^{2+}$ binding (Asn110, Asp155, Gly157, Asp164, and Gly202: PWA number) in PWA are conserved in Flavobacteriaceae, archaeons, and plants, with the exception of Gly157 in PWA that is replaced by Glu in FSA (Glu202). In addition, the three $\mathrm{Zn}^{2+}$-binding residues in PWA (His147, His152, and Cys166) are all conserved in FSA (His194, His199, and Cys214) and the other three archaeal sequences, but no conservation was found in the other two sequences from Flavobacteriaceae.

Domain $\mathrm{C}$ in the $\mathrm{C}$-terminal portion of the protein (residues 394 to 477) folds into a Greek key motif and 


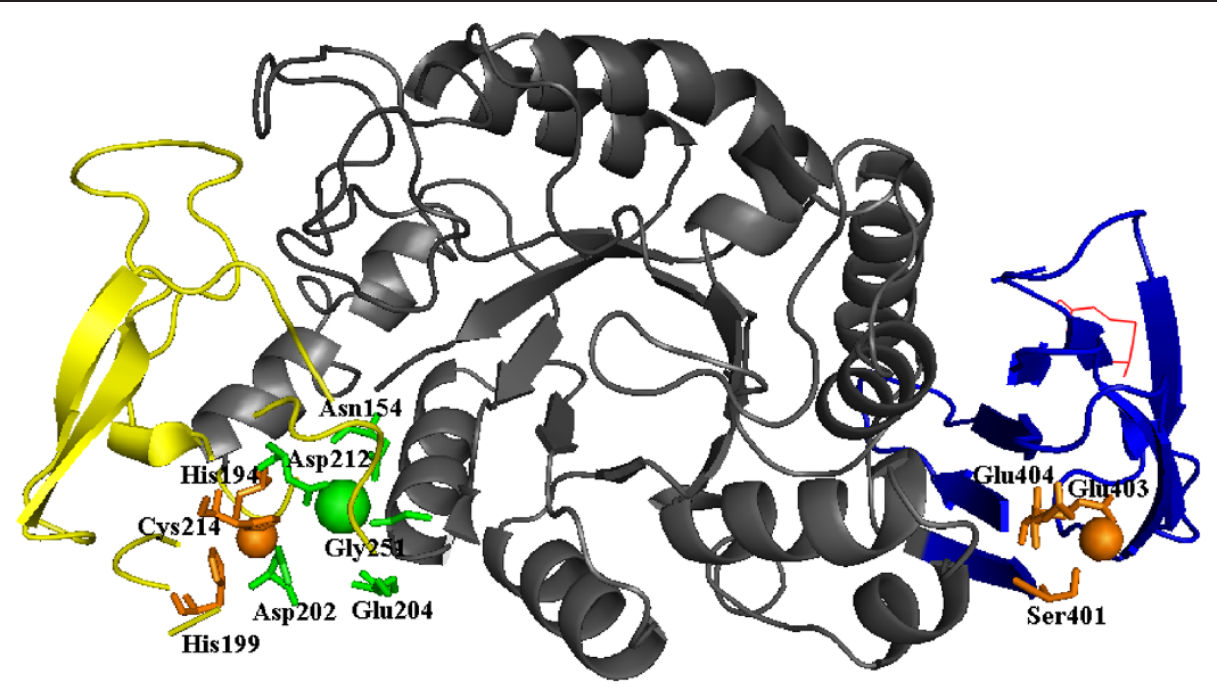

Figure 2 Homology model of FSA and its putative metal-binding sites. The $\mathrm{Ca}^{2+}$ and $\mathrm{Ca}^{2+}$-binding residues are marked as green; the $\mathrm{Zn}^{2+}$ and $\mathrm{Zn}^{2+}$-binding residues are marked as orange; and the introduced disulfide bond is marked as a red line. Domain $\mathrm{A}$ is represented as grey; domain B is represented as yellow; and domain C is represented as blue. FSA, Flavobacteriaceae Sinomicrobium a-amylase.

contains the same numbers of residues as those of the two Flavobacteriaceae $\alpha$-amylases, whereas the four thermophilic archaeal $\alpha$-amylases contain nine additional residues. Among the five cysteines (Cys153, Cys154, Cys166, Cys388, and Cys432) in PWA, only Cys166 (Cys214 in FSA) is conserved in the FSA and FLAJO sequences. Moreover, an additional cysteine at position 296 (FSA numbering) is present in the FSA and FLAJO sequences. As revealed by the crystal structure of PWA, the two disulfide bonds present in the protein structure are formed by two adjacent cysteines (Cys153 and Cys154) in domain B and by Cys388 and Cys432 in domain C, respectively. However, as conferred from the homology model shown in Figure 2, no disulfide bonds were identified in FSA. The additional $\mathrm{Zn}^{2+}{ }^{-}$binding site observed in domain C of PWA (Asp347, Asp349, and Glu350) is well conserved among the Flavobacteriaceae and archaeon sequences, with the exception of FSA in which the corresponding residues are Ser401, Glu403, and Glu404 (Figures 2 and 3).

\section{Physical properties of the recombinant protein}

In the final plasmid pETDuet/FSA, the amylolytic activity was detected on Luria-Bertani (LB) agar plates according to the method described by Jørgensen et al. [27]. After a three-step purification procedure, the purified protein displayed a clear protein band of $52 \mathrm{kDa}$ on SDS-PAGE and one clear band of amylolytic activity, and had a specific activity of $328.6 \mathrm{U} \cdot \mathrm{mg}^{-1}$ at $50^{\circ} \mathrm{C}$ (Figure 4).

Figure 5A shows the $\mathrm{pH}$ profiles for FSA activity. The enzyme displayed high activity at $\mathrm{pH} 6.0$ to 9.0, with maximum activity at $\mathrm{pH}$ 6.0. Moreover, the enzyme is much more stable in the $\mathrm{pH}$ range of 6.0 to 11.0, with no loss of activity after incubation for up to 3 hours. However, it retained lower activity and stability when the $\mathrm{pH}$ was lower than 4.0 (Figure $5 \mathrm{~B}$ ).

The optimal temperature for FSA was determined at pH 6.0 by measuring the activity across a temperature range from $20^{\circ} \mathrm{C}$ to $80^{\circ} \mathrm{C}$. As shown in Figure $5 \mathrm{C}$, the enzyme has maximum $\alpha$-amylase activity at $50^{\circ} \mathrm{C}$ and it retains more than $50 \%$ activity at $60^{\circ} \mathrm{C}$. The enzyme is unstable at high temperature, with a half-life of approximately 25 minutes at $50^{\circ} \mathrm{C}$. Different $\mathrm{Ca}^{2+}$ concentrations differently influence the enzyme thermostability (Figure 5D). $\mathrm{Ca}^{2+}$ could obviously improve the enzyme thermostability but the improvement declined as the $\mathrm{Ca}^{2+}$ concentration increased from $1 \mathrm{mM}$ to $5 \mathrm{mM}$ (data not shown). Therefore, $1 \mathrm{mM} \mathrm{Ca}^{2+}$ was selected as the proper dose for thermostability measurements. Consequently, as shown in Figure 5D, we determined an increased half-life of FSA of 55 minutes at $50^{\circ} \mathrm{C}$.

The purified enzyme hydrolyzes soluble starch, amylopectin, and dextrin as shown in Table 1, whereas no activity was observed toward substrates of maltose, dextran, xylan, and $\beta$-cyclodextrin. The influence of various metal ions on the activity of FSA was tested at pH 6.0 and $50^{\circ} \mathrm{C}$ by measuring the enzyme activity in the presence of $5 \mathrm{mM}$ metal ions (Table 2). The activity was strongly inhibited by the presence of $\mathrm{Zn}^{2+}, \mathrm{Cu}^{2+}$, $\mathrm{Co}^{2+}, \mathrm{Mn}^{2+}, \mathrm{Ni}^{2+}$, and $\mathrm{Cd}^{3+}$, whereas the addition of $\mathrm{Ca}^{2+}$ and $\mathrm{K}^{+}$resulted in little increase of activity $(12 \%$ and $13 \%$, respectively). The kinetic parameters $V_{\max }$ $0.182 \mathrm{mg}(\mathrm{ml} \cdot \mathrm{min})^{-1}, K_{\mathrm{m}} 5.361 \mathrm{mg} \mathrm{ml}^{-1}$, and $K_{\text {cat }} 5.93 \mathrm{~s}^{-1}$ of FSA were calculated from the measured activity using a Lineweaver-Burk plot. 
(See figure on previous page.)

Figure 3 Multiple sequence alignment of FSA and other GH13_5, GH13_6, and GH13_7 a-amylases. Dark and grey backgrounds were adopted to highlight the positions of identical and similar residues, respectively. The positions of the amino acids coordinating the zinc ion are marked as $\mathbf{m}$; those coordinating calcium are marked as *; the mutated residues and FYW region are marked as a red box; the residues conserved in GH13_7 sequences are marked as green; residues conserved in Flavobacteriaceae amylases are marked as red; and residues conserved in both GH13_6 and GH13_7 sequences are marked as blue. FSA, Flavobacteriaceae Sinomicrobium a-amylase; GH13, glycosyl hydrolase family 13.

\section{Properties of the mutant protein}

The plasmid of FSA $\Delta$ SK carrying the mutated gene was obtained by replacing S450 and K415 with cysteines. As shown in Figure 5A, after purification, the mutated protein presented a much broader $\mathrm{pH}$ range of activity than that of wild type FSA. The activity at $\mathrm{pH} 11.0$ is much higher than that of the wild type protein $(60 \%$ relative activity in FSA $\triangle \mathrm{SK}$, and only $10 \%$ relative activity observed in wild type FSA). Similarly, the mutated protein also showed higher stability in neutral or alkaline environments (Figure 5B). Importantly, the thermal properties of the mutant enzyme presented a significant improvement deriving from the establishment of the disulfide bond in domain C. As shown in Figure 5C, FSA $\triangle$ SK was active over a broad temperature range $\left(20^{\circ} \mathrm{C}\right.$ to $\left.100^{\circ} \mathrm{C}\right)$

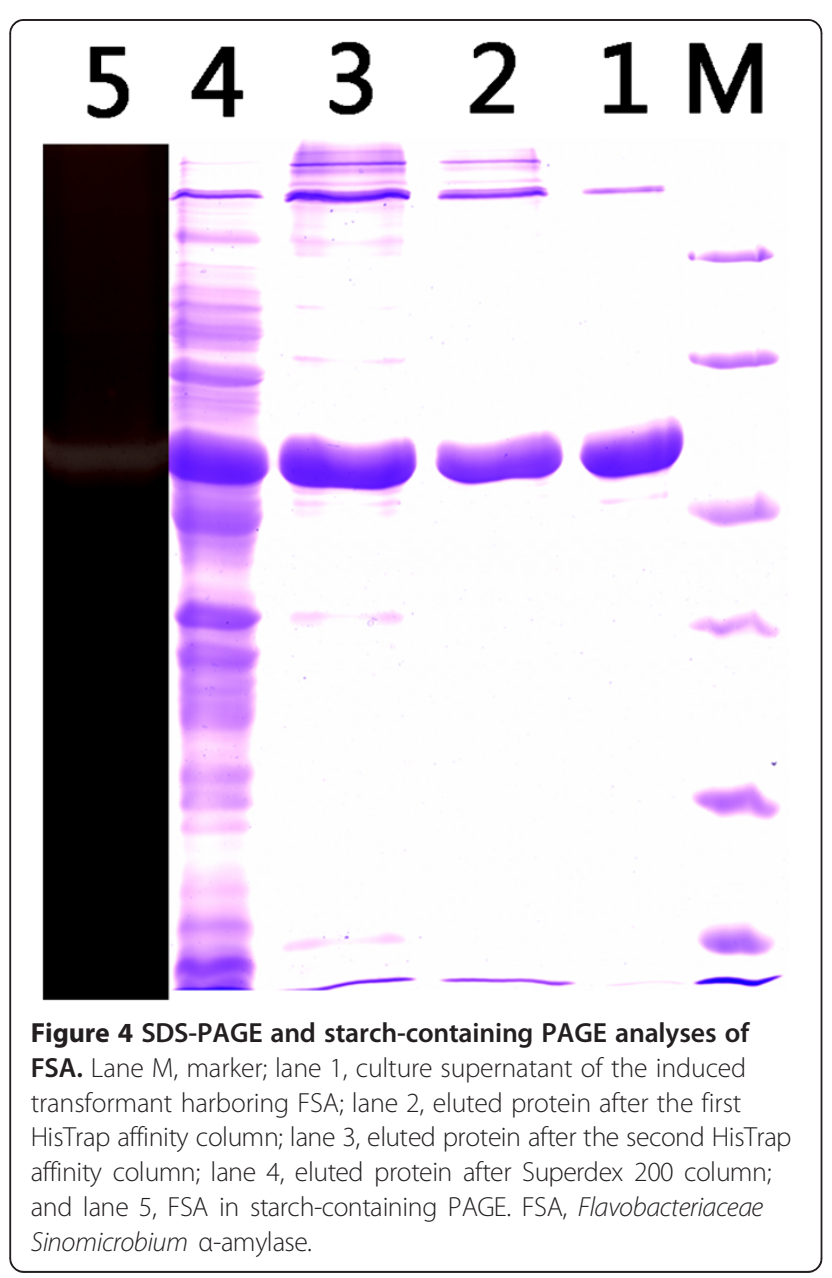

and had an optimum activity at $55^{\circ} \mathrm{C}$. In contrast to the inactivity of the wild type enzyme at $100^{\circ} \mathrm{C}$, more than $50 \%$ activity was detected at $100^{\circ} \mathrm{C}$ for the mutated protein. Despite the absence of $\mathrm{Ca}^{2+}$, FSA $\Delta$ SK exhibits an obviously better thermostability than that of the wild type enzyme. The wild type enzyme exhibited a timedependent decrease in amylolytic activity and had a half-life of 25 minutes at $50^{\circ} \mathrm{C}$, whereas the half-life for FSA $\triangle$ SK was increased to 55 minutes under the same temperature. It is interesting to note that no obvious improvement of the thermostability of the mutated enzyme was detected with the addition of $1 \mathrm{mM} \mathrm{Ca}^{2+}$. As shown in Figure 5D, nearly similar curves were observed in the presence or absence of $\mathrm{Ca}^{2+}$. In the first 10 minutes of the measurement, a slight inhibition of the thermostability was observed followed by a little improvement. Such Ca-independent thermal stability is different from that of the wild type $\alpha$-amylase, as well as many reported $\alpha$-amylases.

\section{Discussions}

Despite the low identity $(<10 \%)$ between the main groups of organisms, most of the within-kingdom $\alpha$-amylases shared higher similarities. Based on the global phylogenetic tree deriving from various $\alpha$-amylases of different origins [28], most of the kingdoms developed their own branches in the tree. However, some exceptions exist concerning bacteria. Obviously, some bacterial, but animal-, plant-, and fungi-like $\alpha$-amylases scattered in related clusters. In the present study, the relatively small phylogenetic analyses among different sources of GH13_5, GH13_6, and GH13_7 $\alpha$-amylases are in agreement with the conclusions from Janeček, according to whom plant and archaeal $\alpha$-amylases from the family GH13 are sequentially similar and evolutionarily related [8]. Bacterial FSA and their Flavobacteriaceae analogues have a special distribution. They share a large branch with thermophilic archaeal $\alpha$-amylases. Such an evolutionary relationship could be explained by the subfamily divisions of the GH13 family according to the CAZy database. Based on the division, numerous bacterial $\alpha$-amylases are grouped into the GH13_5 subfamily except seven Flavobacteriaceae sequences. These seven exceptions belong to the GH13_7 subfamily along with 17 archaeal $\alpha$-amylase sequences. Among these seven $\alpha$-amylases, the enzyme from $F$. johnsoniae was the closest to the archaeal enzymes. Such a close relationship was also confirmed by the multiple 

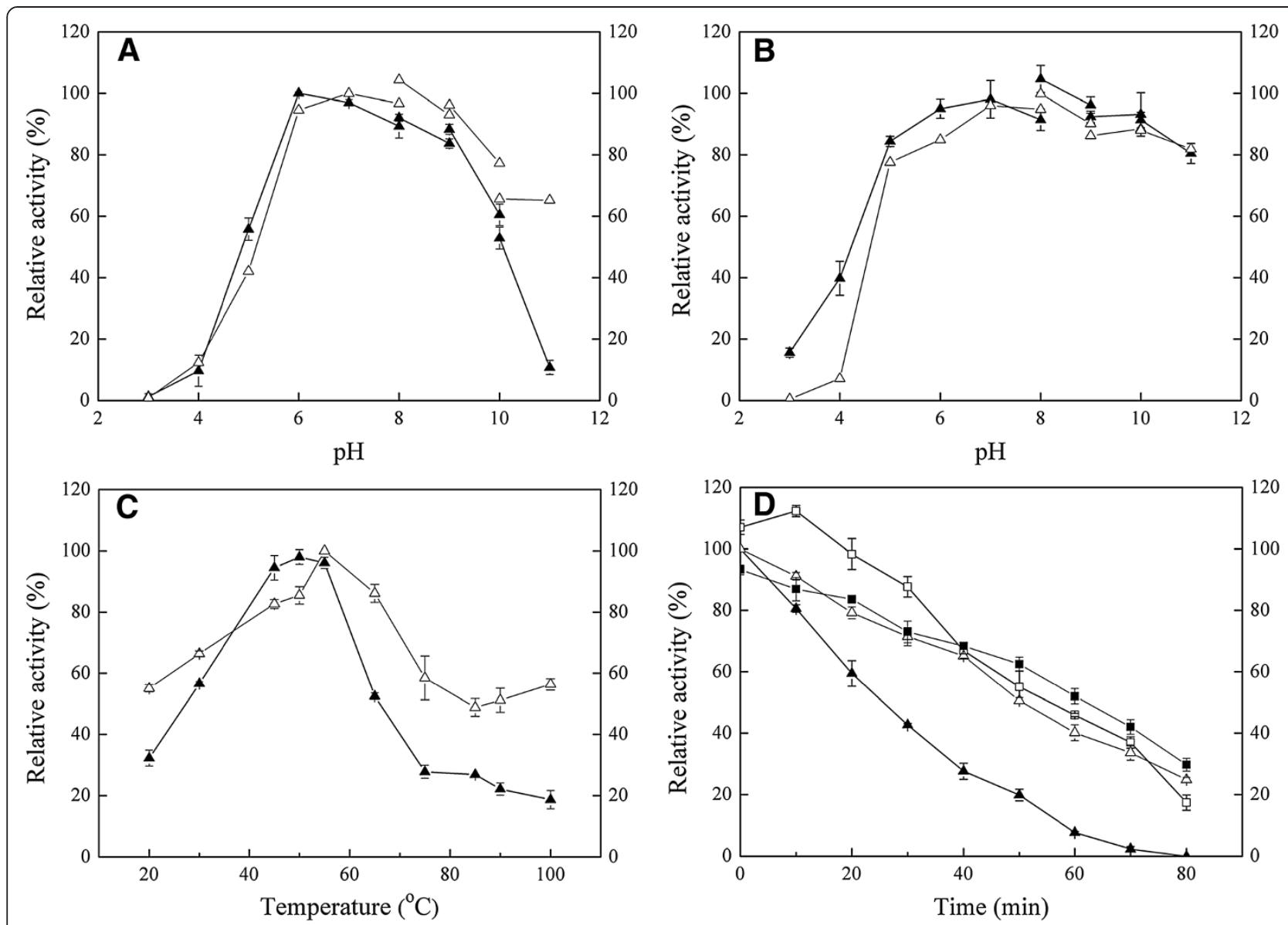

Figure 5 Effects of $\mathrm{pH}$ and temperature on the activity of FSA and mutated protein FSA $\Delta$ SK. (A) pH profile; (B) stability of enzymes at various $\mathrm{pH}$ values; (C) temperature profiles; and (D) time-course curves of enzyme activities at $50^{\circ} \mathrm{C}$. $\boldsymbol{\Delta}$ represents the relative activities of FSA at investigated conditions; and $\Delta$ represents the relative activities of FSA $\Delta$ SK at investigated conditions. In (D), $\boldsymbol{\Delta}$ represents the relative activity of FSA at $50^{\circ} \mathrm{C}$ with no $\mathrm{Ca}^{2+}$ addition; $\triangle$ represents the relative activity of $\mathrm{FSA} \Delta S \mathrm{~K}$ at $50^{\circ} \mathrm{C}$ with no $\mathrm{Ca}^{2+}$ addition; $\square$ represents the relative activity of FSA at $50^{\circ} \mathrm{C}$ in the presence of $1 \mathrm{mM} \mathrm{Ca}{ }^{2+}$; and represents the relative activity of FSA $\triangle S K$ at $50^{\circ} \mathrm{C}$ in the presence of $1 \mathrm{mM} \mathrm{Ca}^{2+}$.

alignments, in which numerous conserved residues were shared between FLAJO and archaeal $\alpha$-amylases.

FSA possesses the common characteristics of other GH13 $\alpha$-amylases: it adopts an $(\alpha / \beta)_{8}$-barrel supersecondary structure with four to seven conserved regions and three consensus residues (that is, Asp247, Glu272,

Table 1 Substrate specificity of the a-amylase FSA from Sinomicrobium sp. 5DNS001

\begin{tabular}{ll}
\hline Substrate & Relative activity (\%) \\
\hline Soluble starch & 100.0 \\
\hline Amylopectin & 66.7 \\
\hline Dextrin & 38.8 \\
\hline Maltose & 0 \\
\hline Dextran & 0 \\
\hline Xylan (Birchwood) & 0 \\
\hline Beta-Cyclodextrin & 0 \\
\hline
\end{tabular}

and Asp334). Besides these characteristics, there are also some features shared with other $\alpha$-amylases or specific to FSA $\alpha$-amylase.

\section{Domain A}

Obviously, most of the conserved residues were located in the six conserved $\beta$-sheets of domain A. Structural information and site-directed mutagenesis of $\alpha$-amylases suggested that some of these residues are important for substrate recognition, specificity, binding, and enzyme stability. Among these highly conserved residues, it is well established that His155 plays an essential role in the binding of the substrate [29-31]. In addition, the carboxylate groups of Trp273, Arg245, and Phe292 form hydrogen bonds with acarbose and are predicated to be substrate-binding sites. Besides these sites, a short conserved stretch covering the strand $\beta 1$ of the catalytic $(\alpha / \beta)_{8}$-barrel was found in various $\alpha$-amylases. Generally, the conserved groups are FYW in archaeal, FNW in 
Table 2 The influence of different metal ions on the activity of FSA

\begin{tabular}{ll}
\hline Metal ion & Relative activity (\%) \\
\hline $\mathrm{K}^{+}$ & 113.2 \\
\hline $\mathrm{Ca}^{2+}$ & 112.5 \\
\hline $\mathrm{Ba}^{2+}$ & 53.1 \\
\hline $\mathrm{Mg}^{2+}$ & 52.3 \\
\hline $\mathrm{Ni}^{2+}$ & 10.4 \\
\hline $\mathrm{Co}^{2+}$ & 7.0 \\
\hline $\mathrm{Cd}^{3+}$ & 0 \\
\hline $\mathrm{Mn}^{2+}$ & 0 \\
\hline $\mathrm{Cu}^{2+}$ & 0 \\
\hline $\mathrm{Zn}^{2+}$ & 0 \\
\hline $\mathrm{EDTA}$ & 0 \\
\hline
\end{tabular}

plant, and FEW in animal $\alpha$-amylases [32]. As shown in Figure 3, the three Flavobacteriaceae sequences also belong to the FYW group. In this group, Tyr39 in T. hydrothermalis was found to contribute to thermostability [33]. Additional conserved sites were found in GH13_6 and GH13_7 subfamilies. Janeček demonstrated that these two families are closely evolutionary related [8]. In particular, Gly251 in the position of $\mathrm{i}+4$ from the catalytic nucleophile Asp247 is a $\mathrm{Ca}^{2+}$-binding site and is only found in these two subfamilies.

\section{Domain B}

It is proposed that domain $B$, which is inserted within the $(\alpha / \beta)_{8}$-barrel at the $\beta 3$ and $\alpha 3$ connection, is the most variable region in the $\alpha$-amylase family [34,35]. However, as shown in Figure 3, high similarity was observed among archaeal and Flavobacteriaceae $\alpha$-amylases with many residues conserved. It was demonstrated by continuous site-directed mutagenesis that domain B plays an important role in liquefying $\alpha$-amylases, because its rigidity offers a substantial improvement in thermostability in $B$. licheniformis $\alpha$-amylase (BLA) compared with $B$. amyloliquefaciens $\alpha$-amylase [5,36]. With few exceptions, all the known $\alpha$-amylases contain a conserved $\mathrm{Ca}^{2+}$ ion located at the interface between domain $\mathrm{A}$ and $\mathrm{B}$ which is essential for their catalytic activity $[4,15,35]$. The role of the conserved $\mathrm{Ca}^{2+}$ is mainly to retain the structural rigidity and activity of the $\alpha$-amylases $[37,38]$. Some Caindependent enzymes have also been reported, such as the thermostable $\alpha$-amylases from $B$. thermooleovorans NP54 and P. furiosus $[39,40]$, and few Bacillus $\alpha$-amylases $[16,41]$. In FSA, $\mathrm{Ca}^{2+}$ did not influence its activity, with only about $10 \%$ increase in the presence of $5 \mathrm{mM} \mathrm{Ca}^{2+}$. However, the thermal stability of FSA was effectively enhanced by the addition of $\mathrm{Ca}^{2+}$, with the half-life of FSA increased by about two fold at $50^{\circ} \mathrm{C}$. Therefore, differently from PWA, which does not require $\mathrm{Ca}^{2+}$ for its thermostability, the $\mathrm{Ca}^{2+}$ ion plays an important role in enzyme thermostability as a stabilizer, yet not as an activator. However, as inferred from the homology model and sequence alignment, the $\mathrm{Ca}^{2+}$-binding sites are also predicted in FSA, with the replacement of only one residue at these binding sites. As shown in Figure 2, the whole binding site appears looser than that of PWA. This might be an explanation for the differences of the two enzymes, both in the $\mathrm{Ca}^{2+}$ ion requirements and the thermostability levels. In accordance with the novel two-metal center $(\mathrm{Ca}, \mathrm{Zn})$ in the PWA structure, a closely similar binding center was also predicted. The $\mathrm{Zn}^{2+}$-binding site with three conserved residues, including Cys178 (Cys166 in PWA), is also found in FSA. It has been demonstrated that Cys166 was not involved in disulfide bridge formation, while it served as one of the coordinating ligands of the PWA (Ca, Zn) metal binding site. If the zinc site of this two-metal center is abolished by replacing its cysteine ligand (Cys166), the thermostability is drastically reduced [42]. Mutagenetic analysis also indicated that the recovery of the $\mathrm{Zn}^{2+}$-binding residues (His175 and Cys189) enhanced the thermostability of $\alpha$-amylase in T. onnurineus NA1 [43].

By sequence comparison and use of Cys166 as an indicator, Linden et al. [15] have demonstrated that the $\mathrm{Zn}^{2+}$ site of the two-metal center is present only in $P$. woesei and its close homolog T. hydrothermalis (84\% sequence identity). Even in the more closely related Archaea sequences from $P$. kodakaraensis and Thermococcus sp., this cysteine is replaced by an alanine. However, it is interesting to note that such residue is conserved in FSA, an enzyme relatively far from PWA compared to the $\alpha$-amylase from P. kodakaraensis and Thermococcus sp. in phylogenetic relationships. However, no such site was found in another two Flavobacteriaceae sequences.

\section{Domain C}

This all- $\beta$ domain is also variable in dimensions and its functional role has not been completely recognized [5]. Domain $C$ in some plant Amy1 and archaeal PWA was found as the substrate-binding site $[15,44]$. In addition, some truncation experiments of domain $C$ suggested that the enzyme activity, as well as stability, was not influenced by the removal of part of the domain $[45,46]$. However, with regard to the structure of isoamylase from Pseudomonas amyloderamosa, this domain was supposed to contribute to the overall catalytic domain stability by shielding the hydrophobic residues of the barrel [47]. It has been demonstrated that the $\mathrm{C}$ terminus of Lactobacillus amylovorus $\alpha$-amylase plays a positive role in the thermostability of the enzyme [48]. The structure of PWA displays an additional metal-binding site $\left(\mathrm{Zn}^{2+}\right.$ or $\left.\mathrm{Mg}^{2+}\right)$ in the loop connecting $\beta$-strands 1 and 2 
of domain C. It has been predicted that this metal binding site has a stabilization role, which may be further enhanced by a nearby disulfide bridge connecting Cys 388 and Cys432 [15]. In the present study, the successful introduction of a disulfide bond at these two sites resulted in significant improvement of the activity and thermostability of FSA. The activity temperature range of FSA was increased to a large extent, with about $50 \%$ activity detected at $100^{\circ} \mathrm{C}$. Moreover, in comparison with the wild type protein, the half-life of the mutated protein at $50^{\circ} \mathrm{C}$ increased by about two fold. As for the activity at different $\mathrm{pH}$ conditions, it is worth noting that the $\mathrm{pH}$ profile of the mutated protein was also shifted to higher values. Many known $\alpha$-amylases including BLA contain structurally essential $\mathrm{Ca}^{2+}$ to maintain their activity and thermostability. However, these $\mathrm{Ca}^{2+}$ are often removed by chelating agents such as zeolite and EDTA, and in turn result in the inactivity of enzymes [49,50]. Therefore, Caindependent enzymes are preferable than $\mathrm{Ca}$-dependent enzymes for industrial applications. In comparison with other Bacillus $\alpha$-amylases (for example BLA), it not only shows higher activity over a broad $\mathrm{pH}$ range from 6.0 to 11.0 , but also does not require $\mathrm{Ca}^{2+}$ for its structural stability. When compared with those thermophilic $\alpha$-amylases of archaea origin (for example PWA), $\mathrm{Ca}^{2+}$ is not necessary for its activity and stability. However, the requirements of anaerobic and extreme growth conditions make them difficult to obtain a sufficient amount of these cells for large-scale enzyme production. Meanwhile, the heterologous proteins were often deposited within the host cells in the form of insoluble inclusion bodies which makes high heterologous expression difficult [51]. In the present study, good properties of broad $\mathrm{pH}$ profile, good $\mathrm{pH}$ stability, Ca-independent, and high expression in host, in combination with special evolutionary status implied good potentials of FSA for various applications.

These improvements demonstrated the important stability role of the disulfide bond in FSA under extreme environments. As shown in Figure 2, a corresponding $\mathrm{Zn}^{2+}$ was also predicated in domain $\mathrm{C}$ corresponding to the conserved residue of E404 in FSA. As shown in Figure 3, this residue is only conserved in the four archaeal and three Flavobacteriaceae sequences. Therefore, as predicated for PWA, the existence of a disulfide bond near the zinc site would play a stability role for the enzyme. Consequently, domain $C$ is supposed to be important in retaining the protein structure under extreme conditions.

\section{Conclusions}

In summary, the novel Flavobacteriaceae $\alpha$-amylases in this study exhibited special evolutionary status and some similar properties such as novel $(\mathrm{Ca}, \mathrm{Zn})$ two-metal center with thermophilic archaeal $\alpha$-amylases. The special evolutionary position suggests its good potentials for thermostability mechanism investigation and directional reconstruction potentials for bioethanol production. Based on the sequence comparisons and homology model analysis, a single disulfide bond in domain $\mathrm{C}$ was introduced in the enzyme and resulted in a significant improvement of the enzyme's properties, including $\mathrm{pH}$ profile shifted toward alkaline $\mathrm{pH}$, thermal activity and thermostability increased to a large extent, and $\mathrm{Ca}^{2+}$ requirement for thermostability disappeared. This successful introduction demonstrates the important role of domain $\mathrm{C}$ in retaining protein stability under extreme conditions. Improved catalytic properties of the engineered enzyme imply good potentials for starch slurry in the majority of industrial production of detergents, textiles, food, paper, and bioethanol.

\section{Methods}

\section{Sampling and strain isolation}

Soils were collected from a salt-making ruin in Dongying city in China, where the Yellow River flows into the sea ( $\left.2 \mathrm{~m}, \mathrm{~N} 37^{\circ} 14^{\prime} 50^{\prime \prime} \mathrm{E} 118^{\circ} 41^{\prime} 11^{\prime \prime}\right)$. The salinity of the soil sample is $0.6 \%$ and the $\mathrm{pH}$ is 9.3 . The strain was isolated from an enrichment of the soil by using the following enrichment medium $(1 \mathrm{~L}): 20 \mathrm{~g}$ of $\mathrm{MgCl}_{2} \cdot 6 \mathrm{H}_{2} \mathrm{O}, 5 \mathrm{~g}$ of $\mathrm{K}_{2} \mathrm{SO}_{4}, 0.1 \mathrm{~g}$ of $\mathrm{CaCl}_{2}, 0.1 \mathrm{~g}$ of yeast extract, $0.5 \mathrm{~g}$ of $\mathrm{NH}_{4} \mathrm{Cl}, 0.05 \mathrm{~g}$ of $\mathrm{KH}_{2} \mathrm{PO}_{4}, 50 \mathrm{~g}$ of $\mathrm{NaCl}, 0.2 \mathrm{~g}$ of Tryptone, $0.5 \mathrm{~g}$ of casein, and $2 \mathrm{~g}$ of citrate sodium. The medium $\mathrm{pH}$ was adjusted to 9.0 with phosphate buffer. After incubation at $25^{\circ} \mathrm{C}$ for 1 week, the strain $5 \mathrm{DNS} 001$ was obtained by spreading the enrichment on the plate, followed by purification.

After cultivation at $25^{\circ} \mathrm{C}$ in $\mathrm{LB}$ medium, the genomic DNA of the strain was isolated with the DNA extraction Kit (Promega, Fitchburg, WI, USA). The 16S rRNA gene was amplified using the universal primers $27 \mathrm{f}$ and 1492r according to a previous report [52], ligated into the pGM-18 T vector (Promega), and transformed into Escherichia coli DH5 $\alpha$ competent cells for sequencing.

\section{Sequence multiple alignment and homology modeling of the FSA}

Genome sequencing for strain 5DNS001 was performed at the Beijing Genomics Institute (BGI, Beijing, China). A genomic DNA library with insert sizes of 500 bp was constructed and sequenced following the Solexa sequencing protocols (Illumina, Inc, San Diego, CA, USA). The sequence of the 5DNS001 gene was submitted to Prokaryotic Genome Automatic Annotation Pipeline (PGAAP) via the website: http://www.ncbi.nlm.nih.gov/genomes/ static/Pipeline.html. Comparatively, a second annotation of rapid annotations using subsystems technology (RAST) service was used to identify and categorize the features of the genome [53]. One ORF designated as FSA putatively 
encoding the $\alpha$-amylase FSA was selected for further study [GenBank:KC441955].

The amino acid sequence of FSA as well as that of other $\alpha$-amylases obtained from the CAZy database, including GH13_5 (bacteria B. licheniformis; fungi Aspergillus niger), GH13_6 (plant Hordeum vulgare), GH13_7 (thermophilic archaeon P. woesei, P. furiosus, T. hydrothermalis, and T. onnurineus; Leeuwenhoekiella blandensis and F. johnsoniae), and other bacterial, fungal, and plant $\alpha$-amylases, were selected for multiple alignments and phylogenetic analyses. Multiple alignments were conducted using the Clustal_X program [54], and the phylogenetic analyses were carried out with MEGA 4 [55]. The homology model of FSA was built using the automated SWISS-MODEL server, by using the crystal structure of $\alpha$-amylase PWA [PDB:1MWO] from $P$. woesei as the template $[56,57]$. The sequence identity between the template and FSA was $43.8 \%$. Visualization and analysis of the structures were undertaken using PyMOL (http://www.pymol.org).

\section{Overexpression and purification of the wild type protein FSA}

Based on the sequence of FSA, the PCR product was generated by using the primers: A-f (5'-CGGGATCCG GATGACAATAATAATTATAC-3') and A-r (5'- GACG TCGACTTACTCTCCCGAAACC-3'), where the restriction sites BamHI and SalI are italicized, respectively. The PCR product was digested, ligated into the expression vector pETDuet-1, and transformed into $E$. coli BL21-CodonPlus. The resulting cells were cultivated in LB medium with the additions of $100 \mu \mathrm{g} \mathrm{ml}^{-1}$ of ampicillin and $40 \mu \mathrm{g} \mathrm{ml}^{-1}$ of chloromycetin. When the cells reached an optical density at $600 \mathrm{~nm}$ of 0.6 to 0.8 , the recombinant protein was induced by adding $1 \mathrm{mM}$ isopropyl $\beta$-D-1-thiogalactopyranoside (IPTG). After 12 hours of incubation at $16^{\circ} \mathrm{C}$, the cells were harvested and washed twice with PBS (pH 7.0), and resuspended in HisTrap buffer A (20 mM PBS, 10\% glycerol, and 0.1 mM PMSF). After lysis by sonication and centrifugation twice at $30,000 \times g$ for 20 minutes at $4^{\circ} \mathrm{C}$, the supernatant was applied to a Ni-NTA HisTrap affinity column (GE Healthcare, Uppsala, Sweden) by using an AKTA Prime System (GE Healthcare). After washing with wash buffer B (20 $\mathrm{mM}$ PBS, $50 \mathrm{mM} \mathrm{NaCl}, 20 \mathrm{mM}$ imidazole, $\mathrm{pH}$ 7.0), the eluted protein was collected and desalted. It was then loaded again on the Ni-NTA HisTrap affinity column as described above. Further purification was obtained by gel filtration on a Superdex 200 column (GE Healthcare) by using the AKTA Prime System. The eluted protein were collected, desalted, and concentrated by ultrafiltration on Vivaspin 20 (molecular weight cut-off, 50,000; Sartorius Stedim Biotech $\mathrm{GmbH}$, Goettingen, Germany). The resulting protein fractions were analyzed by $12 \%$ SDS-
PAGE and starch-containing PAGE as described by Dong et al. [12].

\section{Biochemical properties of FSA}

The enzymatic activity of the purified FSA was determined by measuring the amount of reducing sugar released during the enzymatic hydrolysis of $5 \mathrm{~g} \mathrm{l}^{-1}$ of soluble starch in $50 \mathrm{mM}$ PBS (pH 6.0) at $50^{\circ} \mathrm{C}$ for 15 minutes, unless otherwise stated. Reducing sugar was measured by a modified dinitrosalicylic acid method [58]. One unit of $\alpha$ amylase activity was defined as the amount of enzyme that released $1 \mu \mathrm{mol}$ of reducing sugar as glucose per minute under the assay conditions [59].

For the determination of the optimum $\mathrm{pH}$ for the activity, the following buffers were used for the different pH ranges: $\mathrm{PBS}, \mathrm{pH} 3.0$ to 8.0; Tris- $\mathrm{HCl}, \mathrm{pH} 8.0$ to 9.0; glycine- $\mathrm{NaOH}$, pH 9.0 to 10.0; and $\mathrm{NaHCO}_{3}-\mathrm{NaOH}, \mathrm{pH}$ 10.0 to 11.0. Stability under different $\mathrm{pH}$ conditions was tested by preincubating the enzyme at $25^{\circ} \mathrm{C}$ in different $\mathrm{pH}$ solutions for 3 hours, and residual activity was assayed as described above. The optimal temperature range for the activity of FSA was assayed between $25^{\circ} \mathrm{C}$ to $80^{\circ} \mathrm{C}$ by using soluble starch. To determine the thermostability, the enzyme was incubated at the tested temperatures for 30 minutes before the activity measurement. In addition, FSA was incubated at $50^{\circ} \mathrm{C}$ in $\mathrm{Na}_{2} \mathrm{HPO}_{4}$ citric acid buffer (pH 6.0) in the presence or absence of $1 \mathrm{mM} \mathrm{Ca}^{2+}$. After different time intervals of incubation, the residual activities were measured under the standard assay condition.

The substrate specificity of the $\alpha$-amylase was studied in $50 \mathrm{mM}$ PBS (pH 6.0) at $50^{\circ} \mathrm{C}$ for 15 minutes. The final concentration of various substrates was $1 \%(\mathrm{w} / \mathrm{v})$. The effects of various metal ions such as $\mathrm{K}^{+}, \mathrm{Cu}^{2+}, \mathrm{Co}^{2+}, \mathrm{Zn}^{2+}$, $\mathrm{Ni}^{2+}, \mathrm{Cd}^{2+}, \mathrm{Ca}^{2+}, \mathrm{Mn}^{2+}, \mathrm{Mg}^{2+}, \mathrm{Ba}^{2+}$, and EDTA were tested under the standard assay procedures, with the addition of each ion at a concentration of $5 \mathrm{mM}$. The kinetic parameters toward soluble starch were tested at $50^{\circ} \mathrm{C}$ in PBS buffer ( $\mathrm{pH}$ 6.0).

\section{Site-directed mutagenesis}

Based on the multiple alignments, Ser450 and Lys 415 were replaced by cysteines respectively, using the Mutan BEST kit (TaKaRa Biotechnology, Dalian, China). The mutated protein $(\mathrm{FSA} \triangle \mathrm{SK})$ was generated by using the primers if (5'-CGGGATCCGGATGACAATAATAATT ATAC-3') and 1r (5' - GACGTCGACTTACTCTCCGC AAACCGACC-3') for the S450C mutagenesis, and $2 f$ (5'-CTGGAAAGAGAAATGCCTCG-3') and 2r (5'-TT GGATAAGACGGTTCTTTG-3') for the K415C mutagenesis. Italics indicates the amino acid sequence of mutated sites. The procedure for mutation was conducted according to the manufacturer's instructions (MutanBEST, TaKaRa Biotechnology) and the mutants were sequenced for verification. The resulting proteins were expressed and 
purified as the procedures described for FSA. The purified protein was used to determine the temperature range, thermostability, and $\mathrm{Ca}^{2+}$ requirement for thermostability, using the methods used for FSA. Similarly, to determine the thermostability of the mutant enzyme, it was incubated at $50^{\circ} \mathrm{C}$ in the presence or absence of $1 \mathrm{mM} \mathrm{Ca}^{2+}$. Samples were withdrawn at various incubation periods and tested for residual $\alpha$-amylase activity at $55^{\circ} \mathrm{C}$ under standard assay conditions.

\section{Abbreviations}

BGI: Beijing Genomics Institute; BLA: Bacillus licheniformis a-amylase; CAZy: Carbohydrate-Active Enzymes; EDTA: Ethylenediaminetetraacetic acid; FLAJO: Flavobacterium johnsoniae a-amylase; FSA: Flavobacteriaceae Sinomicrobium a-amylase; GH13: Glycosyl hydrolase family 13; IPTG: Isopropyl B-D-1-thiogalactopyranoside; LB: Luria-Bertani; ORF: Open reading frame; PBS: Phosphate-buffered saline; PCR: Polymerase chain reaction; PGAAP: Prokaryotic Genome Automatic Annotation Pipeline; PMSF:

Phenylmethylsulfonyl fluoride; PWA: Pyrococcus woesei a-amylase;

RAST: Rapid annotations using subsystems technology.

\section{Competing interests}

The authors declare that they have no competing interests.

\section{Authors' contributions}

$\mathrm{CL}$ carried out the characterization, site-directed mutagenesis, and drafted the manuscript. MD carried out the clone and expression of FSA. BC carried out the enzyme purification. CY directed the overall study and revised the manuscript. LW helped to analyze the sequence and structure. XL helped to purify and characterize FSA. CM and PX helped to revise the manuscript. All authors read and approved the final manuscript.

\section{Acknowledgements}

The authors thank the Shandong Science and Technology Fund Planning Project (2011GSF11715) and Shandong University Innovation Fund (2012TS011) for their financial support.

\section{Author details}

${ }^{1}$ State Key Laboratory of Microbial Technology, Shandong University, Jinan 250100, People's Republic of China. ${ }^{2}$ State Key Laboratory of Microbial Metabolism \& School of Life Sciences and Biotechnology, Shanghai Jiao Tong University, Shanghai 200240, People's Republic of China.

Received: 2 September 2013 Accepted: 21 January 2014 Published: 31 January 2014

\section{References}

1. Sánchez OJ, Cardona CA: Trends in biotechnological production of fuel ethanol from different feedstocks. Bioresour Technol 2008, 99(13):5270-5295.

2. Shetty JK, Chotani G, Gang D, Bates D: Cassava as an alternative feedstocks in the production of renewable transportation fuel. Int Sugar J 2007, 109(1307):3-11.

3. de Souza PM, Magalhues PO: Application of microbial a-amylase in industry-a review. Brazilian J Microbiol 2010, 41(4):850-861.

4. Prakash O, Jaiswal N: a-Amylase: an ideal representative of thermostable enzymes. Appl Biochem Biotechnol 2010, 160(8):2401-2414.

5. Alikhajeh J, Khajeh K, Ranjbar B, Naderi-Manesh H, Lin YH, Liu E, Guan HH, Hsieh YC, Chuankhayan P, Huang YC, Jeyaraman J, Liu MY, Chen CJ: Structure of Bacillus amyloliquefaciens a-amylase at high resolution: implications for thermal stability. Acta Crystallograph Sect F Struct Biol Cryst Commun 2010, 66(2):121-129.

6. Linden A, Wilmanns M: Adaptation of class-13 a-amylases to diverse living conditions. Chembiochem 2004, 5(2):231-239.

7. Shiau RJ, Hung HC, Jeang CL: Improving the thermostability of raw-starch-digesting amylase from a Cytophaga sp. by site-directed mutagenesis. Appl Environ Microbiol 2003, 69(4):2383-2385.

8. Janeček $S$, Lévêque $E$, Belarbi A, Haye B: Close evolutionary relatedness of a-amylases from archaea and plants. J Mol Evol 1999, 48(4):421-426.
9. Sivaramakrishnan S, Gangadharan D, Nampoothiri KM, Soccol CR, Pandey A: a-Amylases from microbial sources-an overview on recent developments. Food Technol Biotech 2006, 44(2):173-184.

10. Bentley IS, Williams EC: Starch conversion. In Industrial enzymology. Edited by Godfrey T, West SI. New York: Stockton Press; 1996:339-357.

11. Chung YC, Kobayashi T, Kanai H, Akiba T, Kudo T: Purification and properties of extracellular amylase from the hyperthermophilic archaeon Thermococcus profundus DT5432. Appl Environ Microbiol 1995, 61(4):1502-1506.

12. Dong G, Vieille C, Savchenko A, Zeikus JG: Cloning, sequencing, and expression of the gene encoding extracellular alpha-amylase from Pyrococcus furiosus and biochemical characterization of the recombinant enzyme. Appl Environ Microbiol 1997, 63(9):3569-3576.

13. Koch R, Spreinat A, Lemke K, Antranikian G: Purification and properties of a hyperthermoactive a-amylase from the archaeobacterium Pyrococcus woesei. Arch Microbiol 1991, 155(6):572-578.

14. Lévêque $E$, Haye $B$, Belarbi $A$ : Cloning and expression of an a-amylase encoding gene from the hyperthermophilic archaebacterium Thermococcus hydrothermalis and biochemical characterization of the recombinant enzyme. FEMS Microbiol Lett 2000, 186(1):67-71.

15. Linden A, Mayans O, Meyer-Klaucke W, Antranikian G, Wilmanns M: Differential regulation of a hyperthermophilic a-amylase with a novel (Ca, Zn) two-metal center by zinc. J Biol Chem 2003, 278(11):9875-9884

16. Lee S, Mouri Y, Minoda M, Oneda H, Inouye K: Comparison of the wildtype a-amylase and its variant enzymes in Bacillus amyloliquefaciens in activity and thermal stability, and insights into engineering the thermal stability of Bacillus a-amylase. J Biochem 2006, 139(6):1007-1015.

17. Bauer MW, Driskill LE, Kelly RM: Glycosyl hydrolases from hyperthermophilic microorganisms. Curr Opin Biotechnol 1998, 9(2):141-145.

18. Janeček S, Blesak K: Sequence-structural features and evolutionary relationships of family $\mathrm{GH} 57$ a-amylases and their putative a-amylaselike homologues. Protein J 2011, 30(6):429-435.

19. Henrissat B: A classification of glycosyl hydrolases based on amino acid sequence similarities. J Biochem 1991, 280(2):309-316.

20. Cantarel BL, Coutinho PM, Rancurel C, Bernard T, Lombard V, Henrissat B: The Carbohydrate-Active EnZymes database (CAZy): an expert resource for glycogenomics. Nucleic Acids Res 2009, 37(1):233-238.

21. Stam MR, Danchin EG, Corinne R, Coutinho PM, Henrissat B: Dividing the large glycoside hydrolase family 13 into subfamilies: towards improved functional annotations of a-amylase-related proteins. Protein Eng Des Sel 2006, 19(12):555-562.

22. Majzlová K, Pukajová Z, Janeček S: Tracing the evolution of the a-amylase subfamily GH13_36 covering the amylolytic enzymes intermediate between oligo-1,6-glucosidases and neopullulanases. Carbohydr Res 2013, 367(15):48-57.

23. Janeček S: Amylolytic enzymes-focus on the alpha-amylases from archaea and plants. Nova Biotechnol 2009, 9(1):5-25.

24. Jones RA, Jermiin LS, Easteal S, Patel BK, Beacham IR: Amylase and $16 \mathrm{~S}$ rRNA genes from a hyperthermophilic archaeabacterium. J App/ Microbiol 1999, 86(1):93-107.

25. Janeček S, Svensson B, MacGregor EA: a-Amylase: an enzyme specificity found in various families of glycoside hydrolases. Cell Mol Life Sci 2013. doi: 10.1007/s00018-013-1388-Z

26. Xu Y, Tian XP, Liu YJ, Li J, Kim CJ, Yin H, Li WJ, Zhang S: Sinomicrobium oceani gen. nov., sp. nov., a novel member of the family Flavobacteriaceae isolated from marine sediment. Int I Syst Evol Microbiol 2013, 63(3):1045-1050

27. Jørgensen S, Vorgias CE, Antranikian G: Cloning, sequencing, characterization, and expression of an extracellular alpha-amylase from the hyperthermophilic archaeon Pyrococcus furiosus in Escherichia coli and Bacillus subtilis. J Biol Chem 1997, 272(26):16335-16342.

28. Da Lage JL, Feller $G$, Janeček S: Horizontal gene transfer from Eukarya to bacteria and domain shuffling: the a-amylase model. Cell Mol Life Sci 2004, 61(1):97-109.

29. Gilles C, Astier JP, Marchis-Mouren G, Cambillau C, Payan F: Crystal structure of pig pancreatic a-amylase isoenzyme II, in complex with the carbohydrate inhibitor acarbose. Eur J Biochem 1996, 238(2):561-569.

30. Qian M, Haser R, Buisson G, Duée E, Payan F: The active center of mammalian $a$-amylase. Structure of the complex of a pancreatic $a$-amylase with a carbohydrate inhibitor derived from the X-ray structure analysis to $2.2 \AA$ resolution. Biochemistry 1994, 33(20):6284-6294. 
31. Strokopytov B, Knegtel MA, Penninga D, Rozenboom HJ, Kalk KH, Dijkhuizen L, Dijkstra BW: Structure of cyclodextrin glycosyltransferase complexed with a maltononaose inhibitor at $2.6 \AA$ 年solution. Implications for product specificity. Biochemistry 1996, 35(13):4241-4249.

32. Janeček S: Sequence similarities and evolutionary relationships of microbial, plant and animal a-amylases. Eur J Biochem 1994, 224(2):519-524.

33. Godány A, Majzlová K, Horváthová V, Janeček S: Tyrosine 39 of GH13 a-amylase from Thermococcus hydrothermalis contributes to its thermostability. Biologia 2010, 65(3):408-415.

34. Machius M, Wiegand G, Huber R: Crystal structure of calcium-depleted Bacillus licheniformis a-amylase at 2.2 Å resolution. J Mol Biol 1995, 246(4):545-559.

35. Janeček S: a-Amylase family: molecular biology and evolution. Progr Biophys Mol Biol 1997, 67(1):67-97.

36. Declerck N, Machius M, Wiegand G, Huber R, Gaillardin C: Probing structural determinants specifying high thermostability in Bacillus licheniformis a-amylase. J Mol Biol 2000, 301(4):1041-1057.

37. Larson SB, Greenwood A, Cascio D, Day J, McPherson A: Refined molecular structure of pig pancreatic a-amylase at 2.1 Å resolution. J Mol Biol 1994, 235(5):1560-1584.

38. Machius M, Declerck N, Huber R, Wiegand G: Activation of Bacillus licheniformis a-amylase through a disorder $\rightarrow$ order transition of the substrate-binding site mediated by a calcium-sodium-calcium metal triad. Structure 1998, 6(3):281-292.

39. Malhotra R, Noorwez SM, Satyanarayana T: Production and partial characterization of thermostable and calcium-independent a-amylase of an extreme thermophile Bacillus thermooleovorans NP54. Lett Appl Microbiol 2000, 31(5):378-384.

40. Koch R, Zablowski P, Spreinat A, Antranikian G: Extremely thermostable amylolytic enzyme from the archaebacterium Pyrococcus furiosus. FEMS Microbiol Lett 1990, 71(1-2):21-26.

41. Sajedi RH, Naderi-Manesh H, Khajeh K, Ahmadvand R, Ranjbar B, Asoodeh A, Moradian F: A Ca-independent a-amylase that is active and stable at low pH from the Bacillus sp. KR-8104. Enzyme Microb Technol 2005, 36(5-6):671-671.

42. Savchenko A, Vieille C, Kang S, Zeikus JG: Pyrococcus furiosus a-amylase is stabilized by calcium and zinc. Biochemistry 2002, 41(19):6193-6201.

43. Lim JK, Lee HS, Kim YJ, Bae SS, Jeon JH, Kang SG, Lee JH: Critical factors to high thermostability of an a-amylase from hyperthermophilic archaeon Thermococcus onnurineus NA1. J Microbiol Biotechnol 2007, 17(8):1242-1248.

44. Bozonnet S, Jensen MT, Nielsen MM, Aghajari N, Jensen MH, Kramhøft B, Willemoes M, Tranier S, Haser R, Svensson B: The 'pair of sugar tongs' site on the non-catalytic domain $C$ of barley a-amylase participates in substrate binding and activity. FEBS J 2007, 274(19):5055-5067.

45. Ohdan K, Kuriki T, Kaneko H, Shimada J, Takada T, Fujimoto Z, Mizuno H, Okada S: Characteristics of two forms of a-amylases and structural implication. Appl Environ Microbiol 1999, 65(10):4652-4658.

46. Vihinen M, Peltonen T, litiä A, Suominen I, Mäntsälä P: C-terminal truncations of a thermostable Bacillus stearothermophilus a-amylase. Protein Eng 1994, 7(10):1255-1259.

47. Katsuya Y, Mezaki Y, Kubota M, Matsuura Y: Three-dimensional structure of Pseudomonas isoamylase at 2.2 Å resolution. J Mol Biol 1998, 281(5):885-897.

48. Sanoja RR, Morlon-Guyot J, Jore J, Pintado J, Juge N, Guyot JP: Comparative characterization of complete and truncated forms of Lactobacillus amylovorus a-amylase and the role of the C-terminal direct repeats in raw starch binding. Appl Environ Microbiol 2000, 66(8):3350-3356.

49. Igarashi K, Hatada Y, Ikawa K, Araki H, Ozawa T, Kobayashi T, Ozaki K, Ito S: Improved thermostability of a Bacillus a-amylase by deletion of an arginine-glycine residue is caused by enhanced calcium binding. Biochem Biophys Res Commun 1998, 248(2):372-377.

50. Moranelli F, Yaguchi M, Calleja GB, Nasim A: Purification and characterization of the extracellular a-amylase activity of the yeast Schwanniomyces alluvius. Biochem Cell Biol 1987, 65(10):899-908.

51. Grzybowska B, Szweda P, Synowiecki J: Cloning of the thermostable a-amylase gene from Pyrococcus woesei in Escherichia coli. Mol Biotechnol 2004, 26(2):101-109.

52. Lane D: $16 \mathrm{~S} / 23 \mathrm{~S}$ rRNA sequencing. In Nucleic acid techniques in bacterial systematics. Edited by Stackebrandt E, Goodfellow M. Hoboken, NJ: John Wiley \& Sons; 1991:115-175.

53. Aziz RK, Bartels D, Best AA, DeJongh M, Disz T, Edwards RA, Formsma K, Gerdes S, Glass EM, Kubal M, Meyer F, Olsen GJ, Olson R, Osterman AL,
Overbeek RA, McNeil LK, Paarmann D, Paczian T, Parrello B, Pusch GD, Reich C, Stevens R, Vassieva O, Vonstein V, Wilke A, Zagnitko O: The RAST server: rapid annotations using subsystems technology. BMC Genomics 2008, 9:75.

54. Thompson JD, Gibson TJ, Plewniak F, Jeanmougin F, Higgins DG: The CLUSTAL_X windows interface: flexible strategies for multiple sequence alignment aided by quality analysis tools. Nucleic Acids Res 1997, 25(24):4876-4882

55. Tamura K, Dudley J, Nei M, Kumar S: MEGA4: molecular evolutionary genetics analysis (MEGA) software version 4.0. Mol Biol Evol 2007, 24(8):1596-1599.

56. Peitsch MC: Protein modeling by e-mail. Nat Biotechnol 1995, 13:658-660.

57. Schwede T, Kopp J, Guex N, Peitsch MC: SWISS-MODEL: an automated protein homology-modeling server. Nucleic Acids Res 2003, 31(13):3381-3385.

58. Miller GL: Use of dinitrosalicylic acid reagent for determination of reducing sugar. Anal Chem 1959, 31(3):426-428.

59. Hagihara H, Igarashi $K$, Hayashi $Y$, Endo K, Ikawa-Kitayama K, Ozaki K, Kawai S, Ito S: Novel a-amylase that is highly resistant to chelating reagents and chemical oxidants from the alkaliphilic Bacillus isolate KSM-K38. App/ Environ Microbiol 2001, 67(4):1744-1750.

\section{doi:10.1186/1754-6834-7-18}

Cite this article as: Li et al:: Close relationship of a novel

Flavobacteriaceae a-amylase with archaeal a-amylases and good

potentials for industrial applications. Biotechnology for Biofuels 2014 7:18.

\section{Submit your next manuscript to BioMed Central and take full advantage of:}

- Convenient online submission

- Thorough peer review

- No space constraints or color figure charges

- Immediate publication on acceptance

- Inclusion in PubMed, CAS, Scopus and Google Scholar

- Research which is freely available for redistribution

Submit your manuscript at www.biomedcentral.com/submit
C) Biomed Central 